\title{
PERMASALAHAN YANG DIHADAPI MASYARAKAT DAN PERAN KIMBis DALAM KEHIDUPAN MASYARAKAT KOTA TEGAL
}

\author{
Yayan Hikmayani \\ Balai Besar Penelitian Sosial Ekonomi Kelautan dan Perikanan \\ JI. KS. Tubun Petamburan VI Jakarta 10260 \\ Telp. (021) 53650162, Fax. (021)53650159 \\ e-mail: yayanhikmayani@yahoo.ca
}

Diterima 3 Juli 2012- Disetujui 22 Nopember 2013

\begin{abstract}
ABSTRAK
Klinik IPTEK Mina Bisnis (KIMBis) adalah wadah komunikasi, advokasi/pendampingan, serta konsultasi antara kelompok masyarakat nelayan (perikanan) yang beraktivitas di daerah (pesisir) dengan stakeholder terkait, melalui pendekatan technopreneurship untuk meningkatkan kapasitas ekonomi masyarakat nelayan (perikanan). KIMBis Kota Tegal telah berdiri sejak tahun 2012. Metode yang digunakan dalam riset aksi, diawali dengan melakukan studi dasar, kemudian merumuskan perlakuan yang langsung diikuti dengan tindakan nyata dan setelah dievaluasi dan dikaji ulang dikembangkan perlakuan-perlakuan baru. Kegiatan yang dilakukan bersifat kesinambungan dan evaluasi secara terus menerus. Analisa dilakukan secara evaluatif terhadap berbagai tujuan terkait dengan aspek pengembangan ekonomi masyarakat di lokasi KIMBis. Dari hasil kegiatan yang telah dilakukan diketahui bahwa KIMBis telah berperan dalam mengembangkan ekonomi masyarakat kelautan dan perikanan khususnya untuk kelompok binaan KIMBis..
\end{abstract}

Kata kunci: KIMBis, pengembangan, ekonomi, masyarakat

Abstract : Problems Faced By The Community and Empowerment Organization (KIMBis) Role in Tegal Society. By Yayan Hikmayani.

Science and Technology for Fisheries Business Clinic (KIMBis) is a place of communication, advocacy / assistance, and consultation between fishermen community with relevant stakeholders, through techno-preneurship approach to improve the economic capacity of fishing communities. KIMBis Tegal has been established since 2012. Methods used is action research, beginning with the baseline study, and then formulate treatment to be followed by action and after being evaluated and reviewed, new treatments are developed. Activities undertaken are sustainable and done with continuous evaluation. The analysis is carried out against a variety of evaluative purposes associated with aspects of community economic development at the site KIMBis. From the results of the activities that have been carried out it is known that KIMBis has been instrumental in developing Community fisheries and maritime economy especially for small-scale group KIMBis.

Keywords : KIMBis, development, economy, society

\section{PENDAHULUAN}

Kondisi masyarakat nelayan atau masyarakat pesisir merupakan kelompok masyarakat yang relatif tertinggal secara ekonomi, sosial (khususnya dalam hal akses pendidikan dan layanan kesehatan), dibandingkan dengan kelompok masyarakat lain. Hal ini di perkuat oleh pernyataan Kusnadi (2008) bahwa kemiskinan dan kesulitan hidup nelayan terjadi karena faktor-faktor yang kompleks. Kondisi masyarakat pesisir atau masyarakat nelayan di berbagai kawasan pada umumnya ditandai oleh adanya beberapa ciri, seperti kemiskinan, keterbelakangan sosial budaya, rendahnya sumber daya manusia (SDM) karena sebagian besar penduduknya hanya lulus sekolah dasar atau belum tamat sekolah dasar, dan lemahnya fungsi dari keberadaan Kelompok Usaha Bersama (KUB), Lembaga Keuangan Mikro (LKM), atau kapasitas berorganisasi (Ferdiansyah, 2008). Dari data, dinyatakan bahwa terdapat 10.639 desa pesisir dengan 16.420 .000 jiwa, dan jumlah penduduk yang miskin sebanyak 7.280.000 jiwa. (Kementerian Kelautan dan Perikanan (2010); Hutabarat (2010)).
Hutabarat (2010) menyatakan bahwa dengan jumlah penduduk di desa-desa pesisir yang mencapai 16.420.000 orang, maka potensi pengembangan desa pesisir sangat besar untuk meningkatkan kesejahteraan masyarakat Indonesia. Program-program pemberdayaan masyarakat yang bertujuan untuk meningkatkan taraf hidup masyarakat telah banyak digulirkan baik oleh pemerintah, masyarakat atau pihak swasta. Keberhasilan program pemberdayaan yang dilakukan terletak pada upaya pemberian kesempatan dan atau memfasilitasi kelompok kurang mampu (miskin) agar memiliki aksesibilitas terhadap sumber daya yang berupa modal, teknologi, informasi, jaminan pemasaran dan lainnya agar mampu memajukan dan mengembangkan usahanya. Mardikanto (2010) menyatakan bahwa pemberdayaan bukan hanya meliputi penguatan individu anggota masyarakat, tetapi juga pranata-pranatanya.

Salah satu pendekatan yang mampu digunakan untuk meningkatkan kapasitas individu, yaitu melalui penyediaan kemudahan akses terhadap teknologi. Hal ini perlu dilakukan karena berdasarkan fakta bahwa rendahnya adopsi teknologi oleh nelayan disebabkan 
permasalahan yang terus menerus seperti kesulitan modal usaha serta lemahnya manajemen usaha sehingga tidak dapat meningkatkan kesejahteraan (Syamsir, 2013). Rendahnya adopsi teknologi tersebut menyebabkan produk yang dihasilkan tidak sesuai dengan keinginan pasar, sehingga diperlukan upaya perbaikan melalui aplikasi teknologi dalam kegiatan produksi oleh masyarakat.

KIMBis di Kota Tegal merupakan salah satu KIMBis yang dinilai berhasil dalam mengembangkan ekonomi masyarakat di sektor kelautan dan perikanan (hasil evaluasi internal kegiatan). KIMBIS yang dibentuk di 15 kabupaten/kota dengan basis wilayah kerjanya yaitu desa/kelurahan merupakan kelembagaan yang difungsikan sebagai wadah untuk penerapan Ilmu Pengetahuan dan Teknologi (IPTEK) oleh masyarakat agar hasil usahanya lebih baik. Dalam melaksanakan tugasnya, KIMBis Kota Tegal berfungsi sebagai pusat kegiatan maupun sebagai kelembagaan. Sebagai pusat kegiatan KIMBis Kota Tegal berfungsi sebagai wadah untuk penyebarluasan teknologi khususnya yang dihasilkan oleh Badan Penelitian dan Pengembangan Kelautan dan Perikanan (Balitbang KP) kepada masyarakat. Sebagai kelembagaan, KIMBis Kota Tegal akan terus melakukan upaya penguatan dan pengembangan. Penguatan kelembagaan dilakukan melalui upaya sosialisasi terus menerus tentang fungsi KIMBis Kota Tegal kepada seluruh pelaku dan calon mitra. Pengembangan kelembagaan akan dilakukan terkait dengan perluasan cakupan wilayah kerja KIMBis Kota Tegal dengan menjalin kerjasama bersama seluruh institusi yang terkait.

Melalui makalah ini akan diuraikan fungsi KIMBis sebagai sarana pengembangan ekonomi masyarakat. Sebagai sarana pengembangan ekonomi, KIMBis Kota Tegal harus mampu melaksanakan fungsinya sebagai sarana informasi terkait dengan pasar, manajemen usaha, sumber permodalan melalui pendekatan teknologi.

Dengan kata lain, KIMBis Kota Tegal sebagai sarana pengembangan ekonomi masyarakat berbasis Iptek diharapkan mampu menjembatani kebutuhan pelaku usaha khususnya teknologi yang dibutuhkan dalam upaya meningkatkan kapasitas usahanya melalui upaya pendampingan terhadap pelaku usaha. Peran KIMBis Kota Tegal dalam mendorong pelaku usaha berkembang secara ekonomi akan mampu memberikan efek ganda yang akan menggerakkan sektor lainnya sehingga dapat berperan dalam penumbuhan ekonomi, peningkatan pendapatan dan penyerapan tenaga kerja.

\section{METODOLOGI}

\section{Lokasi dan Waktu}

Pelaksanaan kegiatan penelitian dilakukan pada tahun 2012. Lokasi penelitian di Kecamatan Tegal Barat, Kota Tegal.

\section{Jenis dan Sumberdaya}

Jenis data terdiri dari data primer dan sekunder. Data primer diperoleh melalui wawancara dengan responden kunci yaitu peserta pendampingan teknologi yang disampiakan oleh KIMBis Kota Tegal terdiri dari pengolah makanan dari ikan, pengolah tepung ikan dan nelayan skala kecil

\section{Data yang Dikumpulkan}

Data yang dikumpulkan terdiri dari data keragaan usaha sebelum dan sesudah pendampingan teknologi, akses pasar serta akses permodalan

\section{Metode Pengumpulan dan Analisis Data}

Metode penelitian diawali dengan melakukan studi dasar (identifikasi sosial ekonomi masyarakat yang ada di lokasi), kemudian merumuskan tindakan/ perlakuan yang langsung diikuti dengan tindakan nyata. Hasil tindakan tersebut kemudian dievaluasi dan dikaji ulang serta dikembangkan perlakuan-perlakuan baru. Kegiatan yang dilakukan bersifat berkesinambungan dan dievaluasi secara terus menerus terhadap hasil dari tindakan yang dilakukan. Menurut Mudjiman (1997), menyatakan bahwa kaji tindak atau sering disebut riset aksi adalah merupakan kegiatan riset melalui tindakan, riset dengan tindakan, atau riset untuk menunjang tindakan guna menangani masalah yang penting dan berarti bagi masyarakat. Metode pengambilan responden dilakukan secara sengaja terhadap setiap jenis usaha perikanan yang sudah mendapatkan pendampingan teknologi. Analisa dilakukan secara evaluatif terhadap berbagai tujuan khususnya terkait dengan aspek pengembangan ekonomi masyarakat di lokasi KIMBis Kota Tegal.

\section{PERMASALAHAN YANG DIHADAPI MASYARAKAT KOTA TEGAL}

Permasalahan yang dihadapi oleh masyarakat kelautan dan perikanan pada umumnya terkait dengan potensi ekonomi yang ada, yaitu: (1) Belum optimalnya pemanfaatan sumberdaya ekonomi potensial lokal; (2) Masih rendahnya tingkat adopsi teknologi dan transfer teknologi; (3) Masih buruknya budaya kerja dan kinerja usahanya; (4) Lambatnya modernisasi atau inovasi produk yang dihasilkan.

Sementara itu, isu yang dihadapi dalam persaingan global, pelaku usaha dihadapkan pada daya saing yang semakin ketat sehingga memaksa pelaku usaha harus menjalankan usahanya lebih efisien (Zuhal, 2010). Hal tersebut dapat dilakukan oleh pelaku usaha salah satunya melalui penguasaan teknologi serta inovasi teknologi yang cepat, mampu menggali potensi lokal yang ada serta meningkatkan budaya kerja .

Kota Tegal sebagai salah satu wilayah penting di Jawa Tengah merupakan wilayah penghasil ikan laut 
terbesar nomor tiga di Jawa Tengah. Disamping itu, sektor perikanan di Kota Tegal juga menjadi sumber matapencaharian utama sebagian besar penduduknya. Pembangunan infrastruktur pendukung dilakukan dengan pembangunan sebanyak 4 buah Tempat Pelelangan Ikan (TPI) serta Pelabuhan Perikanan Pantai (PPP). Keseriusan pemerintah untuk mendukung peningkatan produksi tersebut dengan dibangunnya sentra produksi fillet ikan di Tegalsari.

Isu serta permasalahan perikanan tangkap di Kota Tegal, seperti halnya yang terjadi di Pantai Utara pada umumnya yaitu kelangkaan sumberdaya ikan. Fakta semakin berkurangnya sumberdaya ikan tersebut secara langsung telah berdampak pada penurunan hasil tangkapan nelayan.

Isu serta permasalahan pada usaha budidaya ikan diakibatkan semakin menurunnya produktivitas lahan budidaya seperti lahan tambak, penurunan kualitas benih ikan serta penyakit ikan. Budidaya ikan yang dilakukan di Kota Tegal pada awalnya, yaitu periode sebelum tahun 2000 hanya terdiri dari budidaya di lahan tambak dengan komoditas yang dibudidayakan terdiri dari polikultur udang dan bandeng. Seiring dengan perkembangan informasi dan pasar, pada tahun 2010 mulai disosialisasikan budidaya rumput laut Gracillaria $s p$ di tambak. Dengan harga rumput laut saat itu yaitu Rp. $10.000 / \mathrm{kg}$, budidaya rumput laut tersebut sangat menarik keinginan masyarakat untuk menjadi usaha budidayanya. Sementara para pembudidaya ikan di Kota Tegal menghadapi permasalahan penurunan kualitas benih bandeng yang menyebabkan lamanya pemeliharaan. Demikian pula dengan budidaya udang juga di beberapa lokasi sudah tidak dapat dilakukan karena kematian.

Budidaya ikan air tawar mulai diperkenalkan pada tahun 2011 melalui program bantuan PUMP (Pemberdayaan Usaha Mina Pedesaan), yaitu budidaya lele di terpal. Sampai saat ini usaha budidaya ikan lele tersebut masih berlangsung walaupun dengan menggunakan teknologi sederhana dan masih banyak yang harus diperbaiki.

Pembuatan sentra pengolahan fillet di Tegalsari masih mendatangkan permasalahan terhadap lingkungan. Limbah yang dihasilkan dari usaha fillet tersebut tidak kurang dari 100 ton setiap hari. Sarana pengolahan yang belum memenuhi standar rumah olahan ikan menyebabkan pembuangan limbah masih belum tertata dan menyebabkan polusi bau.

Pengolahan limbah fillet menjadi tepung ikan di Kota Tegal sudah dimulai sejak tahun 2005. Jumlah pengolah limbah tersebut terus meningkat sejalan dengan semakin terbukanya pasar tepung ikan. Permasalahannya teknologi pengolahan limbah tersebut hanya mengandalkan dari panas matahari melalui penjemuran. Hal ini menyebabkan polusi bau serta limbah cair yang mengganggu masyarakat

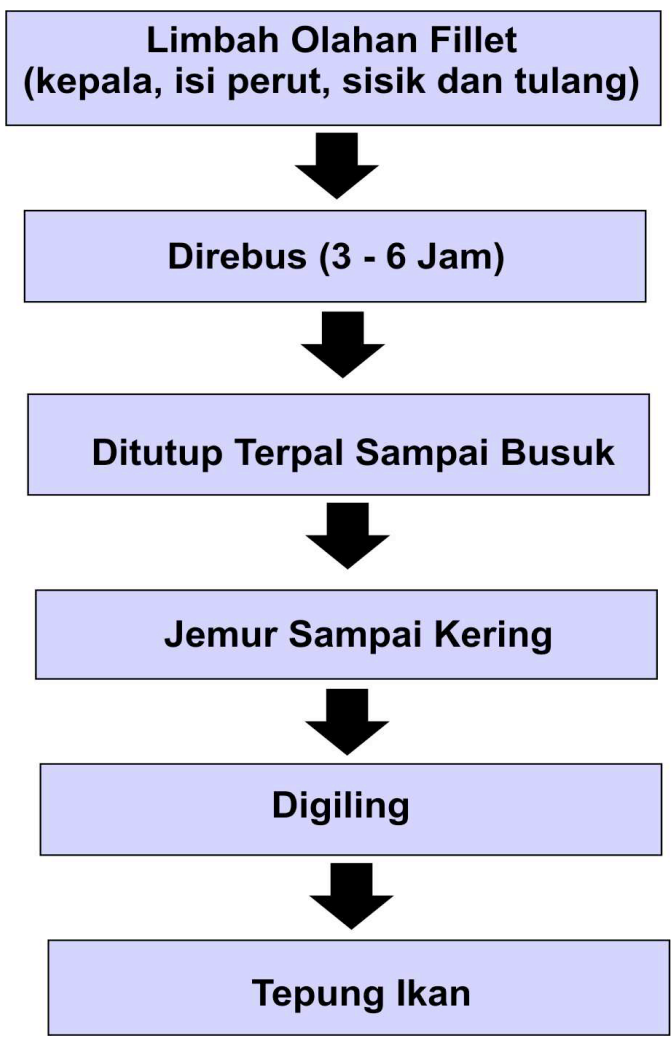

Gambar 1. Skema Pengolahan Tepung Ikan sebelum Penggunaan Teknologi.

Sumber: Pengamatan lapangan (2012)

di Kota Tegal. Proses pembuatan tepung ikan yang dilakukan di Kota Tegal sebelum penggunaan teknologi terlihat pada Gambar 1.

Teknologi pengolahan ikan modern di Kota Tegal tergolong masih belum berkembang. Bentuk olahan ikan didominasi oleh olahan tradisional seperti ikan pindang, asin dan terasi. Atas dasar permasalahan dan isu yang ada, sangat dibutuhkan peningkatan kualitas sumberdaya manusia di sektor kelautan dan perikanan Kota Tegal yakni penguasaan ilmu pengetahuan, keterampilan, sikap, perilaku serta etos kerja. Disamping itu, peningkatan peran perangkat teknis (antara lain mesin dan peralatan) yang diciptakan/ direncanakan untuk peningkatan nilai tambah atau produktivitas. Faktor lainnya, yaitu perangkat organisasi yang memungkinkan terjadinya peningkatan kinerja dan produktivitas terhadap organisasi juga perangkat informasi dan pengetahuan yang berkaitan dengan teknologi yang diterapkan. Kegiatan terkait dengan peningkatan kapasitas usaha masyarakat di Kota Tegal tersebut dapat dilakukan melalui kegiatan (1) Program pendidikan dan latihan, (2) Program magang, (3) Program pendampingan, dan (4) Program katalisator (ikut berpartisipasi langsung pada pelaku usaha sebagai konsultan, manajer, dan lain-lain).

Berkaitan dengan hal-hal tersebut, Klinik Iptek Minabisnis (KIMBis) dalam menjalankan fungsinya 
melakukan kegiatan-kegiatan yang mendukung peningkatan kapasitas usaha masyarakat yaitu melalui usaha pendidikan dan latihan, magang maupun program pendampingan teknologi kepada masyarakat.

\section{PERAN KIMBIS DALAM MEMBERDAYAKAN EKONOMI MASYARAKAT}

Dalam menjalankan perannya, KIMBis berfungsi selain sebagai pusat kegiatan juga berfungsi sebagai kelembagaan. Sebagai pusat kegiatan KIMBis berperan sebagai wadah transfer teknologi yang dibutuhkan masyarakat. Sebagai kelembagaan, maka peran yang dilakukan adalah dengan penguatan dan pengembangan. Penguatan KIMBis dilakukan melalui sosialisasi peran dan fungsi KIMBis kepada seluruh elemen yang memiliki potensi untuk kerjasama dengan KIMBis. Pengembangan KIMBis dilakukan dengan menambah cakupan wilayah kerja di lokasi lain dengan melibatkan seluruh instansi terkait.

Menurut Zulham (2012) keberadaan KIMBis di masyarakat diharapkan mampu menjalankan perannya yaitu :

1. Sebagai sarana pemberdayaan masyarakat berbasis IPTEK

2. Sebagai sarana pengembangan ekonomi masyarakat berbasis IPTEK

3. Sebagai sarana kerjasama peneliti-perekayasapenyuluh dalam penerapan dan penyebaran IPTEK serta memperoleh umpan balik

4. Sebagai mitra kolaborasi (lembaga yang sudah ada, Satuan Kerja Perangkat Pusat (SKPP), Satuan Kerja Perangkat Daerah (SKPD), Swasta dan Lembaga Swadaya Masyarakat (LSM)) dalam pemberdayaan dan pengembangan ekonomi masyarakat

5. Sebagai laboratorium lapangan data sosek kelautan dan perikanan dalam rangka mendukung pembangunanan kelautan dan perikanan

KIMBis Kota Tegal sebagai sarana pengembangan ekonomi bertujuan untuk memacu aktivitas ekonomi masyarakat terutama yang kurang mampu, yang memiliki keterbatasan aksesibilitas dan kemampuan secara ekonomi untuk mengikuti mekanisme pasar. Sebagai sarana pengembangan ekonomi masyarakat, maka KIMBis Kota Tegal melakukan tugasnya dalam menumbuhkan iklim usaha, peningkatan akses terhadap sumberdaya finansial, peningkatan akses pasar dan peningkatan jiwa kewirausahaan dan kemampuan pelaku usaha.

\section{Menumbuhkan Iklim Usaha yang Kondusif}

KIMBis Kota Tegal sebagai sarana untuk menumbuhkan iklim usaha yang kondusif, ditujukan untuk memberikan kesempatan yang sama kepada masyarakat dan pelaku usaha dalam mengembangkan usahanya, termasuk akses kepada sumberdaya produktif yaitu terhadap permodalan, teknologi, sumber informasi dan pasar. Dalam penumbuhan iklim usaha tersebut, KIMBis Kota Tegal mempunyai peluang untuk memberikan masukan kepada pemerintah daerah maupun Dewan Perwakilan Rakyat Daerah (DPRD) Kota Tegal untuk merumuskan, membuat serta mensosialisasikan regulasi serta deregulasi untuk pengembangan ekonomi masyarakat di lokasi.

Kota Tegal merupakan sentra produksi fillet ikan di Jawa Tengah. Produksi total fillet ikan patin mencapai 60 ton per hari. Sebagai lokasi sentra fillet terbesar, diharapkan mampu memberikan kontribusi yang besar bagi peningkatan kesejahteraan masyarakatnya terutama melalui peningkatan kesempatan kerja di perusahaan-perusahaan fillet. Fillet sebagai bahan baku olahan berbagai makanan dari ikan, juga menjadi peluang untuk tumbuhnya usaha-usaha olahan ikan seperti bakso ikan, nugget, sosis, lumpia, abon ikan dan sebagainya. Keberadaan unit olahan fillet tersebut masih belum dimanfaatkan oleh pengolah ikan setempat untuk dimanfatkan lebih lanjut. Kenyataannya, produk fillet ikan tersebut sebagian besar masih dipasarkan di luar kota di antaranya Bandung, Jakarta, Surabaya, Semarang bahkan ke luar Jawa seperti Palembang.

Penciptaan iklim usaha yang kondusif dapat digambarkan dengan adanya kepastian dan kejelasan prosedur perizinan, praktek bisnis dan persaingan usaha yang sehat, koordinasi yang baik antar institusi dalam pemberdayaan masyarakat. Peran KIMBis Kota Tegal dalam menumbuhkan iklim usaha yang kondusif di sektor kelautan dan perikanan secara rinci disajikan pada Tabel 1.

\section{Meningkatkan Akses Masyarakat pada Sumber Finansial}

KIMBis dapat berfungsi sebagai sarana atau wadah untuk meningkatkan akses pada sumberdaya finansial. Permasalahan yang selalu timbul pada usaha kecil, tidak hanya terletak pada permodalan semata, melainkan terkait dengan pasar produk yang dihasilkan justru tidak ada atau pasarnya sedikit sehingga tidak terjual. Keberadaan KIMBis kota Tegal, semestinya mampu melakukan perannya dalam memberi masukan kepada pihak terkait dalam menggulirkan berbagai dana bantuan/hibah untuk pelaku usaha ataupun melalui pendampingan agar memiliki kemampuan untuk menerobos lembaga permodalan/ finansial.

Sulitnya lembaga permodalan/ finansial dalam memberikan akses kepada usaha kecil karena seringkali persyaratan yang ditentukan lembaga tersebut tidak dapat dipenuhi oleh para pelaku pasar. Selain itu, juga dianggap usaha yang dilakukan masih berisiko tinggi. Karena masih lemah dalam penguasaan teknologi, manajemen, informasi dan pasar. Menghadapi permasalahan tersebut pemerintah telah banyak menggulirkan bantuan yang sifatnya sebagai pancingan 
Tabel 1. Peran KIMBis Kota Tegal dalam Menumbuhkan Iklim yang Kondusif Bagi Pengolah makanan dari Ikan di Kota Tegal tahun 2012.

\begin{tabular}{|c|c|c|}
\hline Kegiatan & Produk yang Dihasilkan & Institusi yang Terlibat \\
\hline $\begin{array}{l}\text { Menciptakan kepastian dan } \\
\text { kejelasan prosedur perizinan } \\
\text { yang bertujuan mengurangi } \\
\text { beban administratif dan } \\
\text { hambatan usaha }\end{array}$ & $\begin{array}{l}\text { - Kemudahan pengurusan Perizinan } \\
\text { P-IRT, sertifikat Halal }\end{array}$ & $\begin{array}{l}\text { Dinas Perindustrian } \\
\text { Perdagangan Koperasi dan } \\
\text { UMKM (Disperindagkop } \\
\text { UMKM), Dinas Kesehatan, } \\
\text { Dinas Propinsi, Majelis } \\
\text { Ulama Indonesia (MUI) }\end{array}$ \\
\hline $\begin{array}{l}\text { Mendorong kinerja bisnis dan } \\
\text { persaingan usaha yang sehat }\end{array}$ & $\begin{array}{ll}\text { - } & \text { Spesialisasi produk anggota } \\
& \text { kelompok } \\
\text { - } & \text { Standarisasi bahan baku } \\
& \text { pembuatan olahan ikan } \\
\text { - } & \text { Pemasaran di satu outlet }\end{array}$ & $\begin{array}{l}\text { Kelompok pengolah } \\
\text { makanan dari ikan, Baitul } \\
\text { Maal wa Tamil (BMT)BUM } \\
\text { (Bina Umat Mandiri) }\end{array}$ \\
\hline $\begin{array}{l}\text { Meningkatkan koordinasi antara } \\
\text { institusi Bisnis/usaha dengan } \\
\text { pemerintah dan masyarakat }\end{array}$ & $\begin{array}{l}\text { - Pendampingan dalam rangka } \\
\text { pengembangan kapasitas } \\
\text { pengolah }\end{array}$ & $\begin{array}{l}\text { Disperindagkop UMKM, } \\
\text { Dinas Kelautan dan } \\
\text { Perikanan, Dinas Propinsi, } \\
\text { MUI }\end{array}$ \\
\hline
\end{tabular}

Sumber : Hasil pengamatan lapangan (2012)

untuk dapat mengungkit usaha yang dilakukan. Kredit-kredit murah yang tersedia dengan bunga ringan diantaranya KUR (Kredit Usaha Rakyat, Kredit pangan atau bantuan yang sifatnya natura seperti PUMP (Pemberdayaan Usaha Mina Pedesaan) dari Kementerian kelautan dan Perikanan yang ditujukan untuk nelayan, pengolah dan pembudidaya ikan. Demikian pula dengan KIMBis kota Tegal, yang telah melakukan berbagai upaya untuk membantu mengurangi permasalahan tersebut, yaitu seperti terlihat pada Tabel 2

\section{Meningkatkan Akses Masyarakat Terhadap Pasar}

Peningkatan akses pasar dapat dilakukan melalui upaya promosi atau pameran, peningkatan kualitas, desain, dan harga yang bersaing. Kesulitan akses pasar akan berdampak pada kecilnya pemasaran produk usaha kecil. Peningkatan akses pasar dapat dilakukan melalui penyederhanaan regulasi yang dibuat dan dikeluarkan oleh pemerintah. Dari pelaku usaha juga dibutuhkan kemampuan terus melakukan inovasi produk yang dihasilkan sehingga sesuai dengan kebutuhan dan keinginan pasar.

Peran KIMBis Kota Tegal untuk meningkatkan akses pasar produk dari pelaku usaha dilakukan melalui pendampingan untuk meningkatkan keterampilan dan manajemen usaha. Hal ini dimaksudkan untuk meningkatkan kemampuan pelaku usaha dalam memproduksi produk berkualitas dan sesuai dengan kebutuhan konsumen. Di samping pelatihan, temu bisnis dan pameran produk yang dihasilkan harus terus dilakukan. Secara rinci peran KIMBis kota Tegal dalam meningkatkan akses pasar dapat disajikan pada Tabel 3.

\section{Meningkatkan Jiwa Kewirausahaan Pelaku Usaha}

Menurut As`ad (2003), wirausahawan adalah individu yang memiliki kemampuan dan sikap mandiri, kreatif, inovatif, ulet, berpandangan jauh ke depan, pengambilan risiko yang sedang dan tanpa mengabaikan orang lain dalam bidangnya atau masyarakat. Seseorang

Tabel 2. Peran KIMBis dalam Meningkatkan Akses Masyarakat Pada Sumberdaya Finansial Bagi Pengolah Ikan dan Nelayan Skala Kecil di Kota Tegal Tahun 2012.

\begin{tabular}{lll}
\hline \multicolumn{1}{c}{ Upaya } & \multicolumn{1}{c}{ Produk yang dihasilkan } & \multicolumn{1}{c}{ Institusi yang terlibat } \\
\hline $\begin{array}{l}\text { Perbaikan Manajemen } \\
\text { Usaha }\end{array}$ & $\begin{array}{l}\text { Aplikasi akuntansi Pembukuan pada } \\
\text { kelompok Diversifikasi olahan ikan } \\
\text { (Kelompok Sari Ulam) }\end{array}$ & $\begin{array}{l}\text { BMT, KIMBis, Koperasi Sari Ulam, } \\
\text { Kelompok Pengolah Sari Ulam }\end{array}$ \\
$\begin{array}{l}\text { Pengelolaan Keuangan } \\
\text { Dana Bantuan }\end{array}$ & $\begin{array}{l}\text { Aplikasi pengguliran dana bantuan } \\
\text { program PUMP oleh nelayan penerima } \\
\text { program (modal mandiri) }\end{array}$ & $\begin{array}{l}\text { Penyuluh Badan Penyuluh Perikanan } \\
\text { dan Pertanian Kehutanan } \\
\text { KIMBis, Dinas Kelautan dan Pertanian, } \\
\text { Kelompok Nelayan }\end{array}$
\end{tabular}

Sumber: Hasil pengamatan lapangan (2012) 
Tabel 3. Peran KIMBis dalam Meningkatkan akses pasar di Kota Tegal Tahun 2012.

\begin{tabular}{|c|c|c|}
\hline Kegiatan & Produk yang dihasilkan & Institusi yang terlibat \\
\hline $\begin{array}{l}\text { Meningkatkan mutu } \\
\text { produk olahan }\end{array}$ & $\begin{array}{l}\text { - Diversifikasi produk olahan } \\
\text { - Perbaikan tampilan/desain kemasan } \\
\text { dan packaging }\end{array}$ & $\begin{array}{l}\text { - Dinas Koperasi, UMKM, Dinas } \\
\text { Kelautan dan Pertanian, PEDEF, } \\
\text { Kelompok pengolah, KIMBis }\end{array}$ \\
\hline $\begin{array}{l}\text { Keikutsertaan dalam } \\
\text { pameran dan promosi }\end{array}$ & $\begin{array}{l}\text { - } \quad \text { Pameran dalam kota ( HUT Kota Tegal, } \\
\text { Tegal Bahari) } \\
\text { - } \quad \text { Pameran tingkat propinsi } \\
\text { - } \quad \text { Pameran yang dilakukan oleh KIMBis } \\
\text { Pusat (KIMBis Expo) }\end{array}$ & \\
\hline $\begin{array}{l}\text { Perbaikan Sarana } \\
\text { Prasarana }\end{array}$ & $\begin{array}{l}\text { - Pemberian sepeda motor yang } \\
\text { dilengkapi coolbox. Mesin pengaduk, } \\
\text { mesin pembuat bakso dan lain lain }\end{array}$ & $\begin{array}{l}\text { - Dirjen P2HP, Dinas } \\
\text {-Disperindagkop UMKM }\end{array}$ \\
\hline
\end{tabular}

Sumber: Hasil pengamatan lapangan (2012)

dikatakan sebagai wirausahawan jika memiliki sifat/ karakter, sikap dan kemampuan wirausaha serta mampu mewujudkannya yang ditunjukkan dengan kinerjanya (Nurhayati et al., 2011).

Rendahnya kewirausahaan dapat dilihat dari kurangnya kreativitas dan inovasi serta keberanian dalam pengambilan keputusan. KIMBis kota Tegal harus mampu mengembangkan wirausaha-wirausaha yang tangguh yang berbasis pada sumber daya lokal atau resources based; mendorong wirausaha dari kelompok pelaku usaha yang berbasiskan teknologi (IPTEK). Menurut Sriyana (2010), menyatakan bahwa penguasaan teknologi merupakan salah satu faktor penting bagi pengembangan usaha kecil menengah.

Hal ini dapat dilakukan dengan mendorong pengembangan inkubator bisnis, baik dengan perguruan tinggi yang ada di lokasi KIMBis maupun melalui peran dunia usaha besar. Sasaran yang akan dicapai adalah berkembangnya pengetahuan serta sikap wirausaha, meningkatnya produktivitas, tumbuhnya unit usaha baru berbasis pengetahuan dan teknologi, berkembangnya ragam produk unggulan usaha kecil sesuai dengan potensi daerahnya dan menjadikan usaha kecil yang feasible menjadi bankable.

\section{Memberdayakan Usaha Mikro}

Usaha perikanan sebagian besar masih merupakan usaha mikro kecil dan menengah (UMKM). Sesuai dengan kondisinya, usaha mikro kecil tersebut memiliki ciri terbatasnya teknologi, kemampuan sumberdaya manusia, akses terhadap pasar serta permodalan. Keterbatasan tersebut menyebabkan usahanya sulit berkembang. Usaha pemberdayaaan terhadap pelaku usaha mikro kecil banyak dilakukan oleh pemerintah, melalui berbagai fasilitasi seperti kemitraan maupun akses terhadap perbankan.

Pemberdayaan usaha mikro melalui KIMBis dilakukan melalui upaya yang dilakukan dalam meningkatkan kapasitas pelaku tersebut dalam menjalankan usahanya. Hal ini dilakukan berdasarkan

Tabel 4. Peran KIMBis dalam Meningkatkan Jiwa Kewirausahaan dan Kemampuan Pelaku Usaha di Kota Tegal Tahun 2012.

\begin{tabular}{|c|c|c|}
\hline Kegiatan & Produk yang dihasilkan & Institusi yang terlibat \\
\hline Perluasan informasi pasar & $\begin{array}{l}\text { - Penggunaan media promosi } \\
\text { dan pemesanan produk dengan } \\
\text { menggunakan jejaring sosial }\end{array}$ & - Kelompok pengolah dan KIMBis \\
\hline Perluasan jejaring usaha & $\begin{array}{l}\text { - } \text { Pengembangan jejaring } \\
\text { pemasaran produk olahan } \\
\text { - Tumbuh usaha-usaha baru } \\
\text { pengolahan ikan }\end{array}$ & $\begin{array}{l}\text { - Disperindagkop Umkm, Dinas } \\
\text { Pertanian, Peternakan dan } \\
\text { Kelautan, PEDEF }\end{array}$ \\
\hline $\begin{array}{l}\text { Perluasana pengetahuan } \\
\text { terhadap teknologi }\end{array}$ & $\begin{array}{l}\text { - Penggunaan teknologi } \\
\text { pengolahan dalam praktek } \\
\text { usahanya }\end{array}$ & $\begin{array}{l}\text { - KIMBis, Disperindagkop UMKM, } \\
\text { Dinas Pertanian, Peternakan } \\
\text { dan Kelautan, PEDEF }\end{array}$ \\
\hline $\begin{array}{l}\text { Pengembangan inkubator } \\
\text { bisnis }\end{array}$ & $\begin{array}{l}\text { - Penciptaan jejaring kerja dg } \\
\text { Carrefour }\end{array}$ & $\begin{array}{l}\text { - Disperindagkop UMKM, } \\
\text { Carrefour }\end{array}$ \\
\hline
\end{tabular}

Sumber: Hasil pengamatan lapangan (2012) 
Tabel 5. Peran KIMBis dalam Memberdayakan Usaha Mikro di Kota Tegal Tahun 2012.

\begin{tabular}{lll}
\multicolumn{1}{c}{ Kegiatan } & Produk yang dihasilkan & \multicolumn{1}{c}{ Instansi yang terlibat } \\
\hline Meningkatkan & - Ragam olahan meningkat & - KIMBis, Disperindagkop UMKM, \\
kapasitas usaha dengan & - Jumlah hasil olahan & Dinas Pertanian, Peternakan dan \\
implementasi teknologi & meningkat & Kelautan, Swasta (Rizky food), \\
pengolahan & & Kelompok pengolah \\
Meningkatkan & - Peningkatan akses produk & - PEDEF, KIMBis, Disperindagkop \\
Keterampilan Pengelolaan & ke pasar & UMKM, Dinas Pertanian, Peternakan \\
Usaha & - Peningkatan omzet & dan Kelautan \\
& produksi &
\end{tabular}

Sumber: Hasil pengamatan lapangan (2012)

rendahnya kompetensi kewirausahaan pelaku usaha kecil yang ada. Peningkatan produktivitas usaha kecil sangat diperlukan untuk mengatasi ketimpangan antarpelaku, antargolongan pendapatan dan antardaerah, termasuk penanggulangan kemiskinan. Sasaran dari peran KIMBis Kota Tegal dalam memberdayakan usaha mikro, yaitu meningkatnya kapasitas usaha kecil, meningkatnya ketrampilan pengelolaan usaha, dan terselenggaranya kepastian, perlindungan, serta pembinaan usaha.

\section{KESIMPULAN}

KIMBis Kota Tegal sebagai lembaga bentukan baru bukan sebagai pesaing yang sudah ada namun menjadi mitra kerja yang bertujuan sama untuk meningkatkan kapasitas masyarakat pelaku usaha khususnya di sektor kelautan dan perikanan. Pendekatan upaya yang dilakukan oleh KIMBis Kota Tegal melalui upaya transfer teknologi untuk memperbaiki teknologi yang sudah ada dan digunakan oleh masyarakat agar lebih efisien dan berdaya saing. Dalam melakukan fungsinya tersebut, KIMBis bekerja sebagai mitra seluruh elemen baik pemerintah maupun swasta yang ada di lokasi KIMBis, baik tingkat pusat maupun daerah.

Sebagai sarana pengembangan ekonomi, KIMBis Kota Tegal melakukan perannya berdasarkan atas isu serta permasalahan yang ada dan dihadapi oleh masyarakat yang berusaha di sektor kelautan dan perikanan. Peran KIMBis Kota Tegal dalam pengembangan ekonomi masyarakat tersebut, yaitu (1) Sebagai sarana untuk menumbuhkan iklim usaha yang kondusif, (2) Sebagai sarana untuk peningkatan akses pada sumberdaya finansial; (3) Sebagai sarana untuk peningkatan akses pasar; (4) Sebagai sarana untuk peningkatan jiwa kewirausahaan dan kemampuan pelaku usaha; dan (5) Sebagai sarana pemberdayaan usaha mikro.

KIMBis sebagai mitra kerja institusi yag ada khususnya di lokasi akan berjalan baik apabila terjadi sinkronisasi program khususnya program-program pemberdayaan. Untuk itu, diperlukan terjadinya komunikasi yang baik antara berbagai pengambil kebijakan baik pusat dan daerah dalam mensinkronkan kegiatan pemberdayaan yang ada di lokasi

\section{DAFTAR PUSTAKA}

As`ad. 2003. Seri Ilmu dan Sumber Daya Manusia: Psikologi Industri dan Organisasi. Yogyakarta: Liberty. Yogyakarta.

Ferdiansyah, A.M. 2008. Evaluasi Kinerja Program Pemberdayaan Ekonomi Masyarakat Pesisir (PEMP) Di Kecamatan Tugu, Semarang. Skripsi. Jurusan IImu Administrasi Publik Fakultas IImu Sosial Dan Ilmu Politik. Universitas Diponegoro. Semarang:

Hutabarat, S. 2010. Pengembangan Desa Pesisir Harus Optimal. www.kkp.go.id. diakses pada tanggal 2 Nopember 2012.

Irianto, H.E dan I. Susilo. 2007. Dukungan Teknologi Penyediaan Produk Perikanan. Makalah disampaikan pada Seminar Nasional Hari Pangan Sedunia 2007 di Auditorium II Kampus Penelitian Pertanian Cimanggu Bogor, 21 November 2007. Badan Penelitian dan Pengembangan Kelautan dan Pertanian. Jakarta.

Kusnadi. 2008. Akar kemiskinan Nelayan. LKIS Jogjakarta. 148 halaman

Mardikanto, T., E. Lestary, S. Anantanyu, K. Saddono. 2010. Konsep-konsep pemberdayaan masyarakat: acuan bagi aparat birokrasi, akademi, praktisi, dan peminat/pemerhati pemberdayaan masyarakat. Fakultas Pertanian. Universitas Sebelas Maret. 392 hal

Mudjiman, H. 1997 dalam Ravik Karsidi (2001). Riset aksi sebagai Metode Pembinaan Masyarakat Desa. Pidato Pengukuhan Guru Besar di Universitas Sebelas Maret.

Nurhayati, P., Sarianti T., Daryanto, H.T., Muflikh, Y.N. 2011. Analisis Pengaruh Karakteristik Kewirausahaan Terhadap Kinerja Wirausaha 
Pada Unit Usaha Kecil Menengah (UKM) Agroindustri Di Kabupaten Bogor. Pros. Sem. Penelitian Unggulan Departmen Agribisnis. FEM, Departemen Agribisnis. IPB. Bogor. 225255 hal

Karsidi, R. 2001. Kaji Tindak: Bentuk Aplikasi Pemberdayakan Masyarakat Oleh Perguruan Tinggi. Disampaikan Dalam Pelatihan Metodologi Pengabdian Kepada Masyarakat Bagi Dosen Ptn-Pts Se-Surakarta, LPM UNS, Solo 12-13 Nopember 2001.

Soetomo. 2011. Pemberdayaan masyarakat "mungkinkah muncul antitesisnya. Pustaka Pelajar. Yogyakarta. 280 hal.

Sriyana, J. 2010. Strategi Pengembangan Usaha Kecil Dan Menengah (UKM): Studi Kasus Di Kabupaten
Bantul. Makalah yang dipresentasikan pada acara Simposium Nasional 2010: Menuju Purworejo Dinamis dan Kreatif - Fakultas Ekonomi Universitas Islam Indonesia. Yogyakarta.

Syamsir, R.E. 2013. Adopsi Teknologi Nelayan Masih Rendah. http://kepri. antaranews. com / berita/27009/adopsi-teknologi-nelayan-masihrendah. Diakses tanggal 30 Nopember 2013.

Zuhal. 2010. Knowledge \& Innovation : Platform Kekuatan Daya Saing. PT Gramedia Pustaka Utama. Jakarta. 485 hal

Zulham, A. 2012. Peran Tugas dan Fungsi Klinik IPTEK Mina Bisnis. Modul Peningkatan Kapasitas Kelembagaan KIMBis Tahun 2012. BBPSEKP. Jakarta. 